\title{
Outcomes of Infants Born to HIV-Infected Women Identified by Rapid HIV Testing Late in Pregnancy or at Delivery: The MIRIAD Study
}

Russell B Van Dyke ${ }^{1 *}$, Susan P Danner ${ }^{2}$, Sarah Chrestman ${ }^{3}$, Patricia Kissinger $^{3}$, Steven Nesheim ${ }^{2,9}$, Angela M Amedee $^{5}$, Gwendolyn Scott ${ }^{6}$, Mardge H Cohen ${ }^{7}$, Elaine J Abrams ${ }^{8}$, Denise J Jamieson ${ }^{4}$, Mary Glenn Fowler ${ }^{2,10}$, Athena P Kourtis ${ }^{4}$, Marc Bulterys ${ }^{2,11}$ for the MIRIAD Study

\section{Group}

${ }^{1}$ Department of Pediatrics, Tulane University School of Medicine, New Orleans, LA, USA

${ }^{2}$ Division of HIVIAIDS Prevention, National Center for HIV, Viral Hepatitis, STD and Tuberculosis Prevention, Centers for Disease Control and Prevention (CDC), Atlanta, GA, USA

${ }^{3}$ Department of Epidemiology, Tulane University School of Public Health and Tropical Medicine, New Orleans, LA, USA

${ }^{4}$ Division of Reproductive Health, National Center for Chronic Disease Prevention and Health Promotion, CDC, Atlanta, GA, USA

${ }^{5}$ Department of Microbiology, Louisiana State University Health Sciences Center, New Orleans, LA, USA

${ }^{6}$ Department of Pediatrics, University of Miami School of Medicine, Miami, FL, USA

${ }^{7}$ Department of Medicine, Cook County Bureau of Health Services and Rush University, Chicago, IL, USA

${ }^{8}$ Department of Pediatrics, Harlem Hospital Center and College of Physicians \& Surgeons, Columbia University, New York, NY, USA

${ }^{9}$ Department of Pediatrics, Emory University, Atlanta, GA, USA

${ }^{10}$ Makerere University Johns Hopkins University (MUJHU) AIDS Research Collaboration, Kampala, Uganda

${ }^{11}$ US Department of Defense HIVIAIDS Prevention Program (DHAPP), Naval Health Research Center, San Diego, CA, USA

\section{Abstract}

Background: Rapid HIV testing late in pregnancy or at delivery provides a final opportunity (among non-breastfeeding mothers) to identify HIV-infected women and initiate antiretroviral drugs to prevent mother-to-child transmission.

Methods: MIRIAD was a CDC-funded study conducted from 2001-2005 at 17 hospitals in 6 US cities. Eligible women had undocumented HIV status when presenting in labor or after 34 weeks gestation and not in labor. We performed both rapid HIV-1 antibody testing of blood and conventional enzyme immunoassay with Western blot confirmation. Women and infants were managed according to the local standard of care. Infant infection status was determined by HIV DNA or RNA PCR testing.

Results: Fifty-one infants (1 pair of twins) were born to 50 women. Among those with data available, $17 \%$ of women received prenatal antiretroviral and $71 \%$ received intrapartum antiretroviral, including $64 \%$ of those identified during labor. All 49 infants with available data received antiretroviral. Forty-four infants had adequate samples to determine their infection status and 5 were infected $(11.4 \%, 95 \% \mathrm{Cl}: 1.9-20.7 \%) ; 3$ had in utero, 1 intrapartum, and 1 indeterminate timing of transmission. No infant whose mother received prenatal antiretroviral was infected. The estimated rate of intrapartum transmission among infants with defined infection status was $4.5 \%$.

Conclusions: Rapid HIV testing late in pregnancy or even during labor, allowing the administration of antiretroviral to infected women, reduces intrapartum HIV transmission. This highlights the importance of offering rapid HIV testing to pregnant women, with unknown HIV status late in pregnancy.

Keywords: Antiretroviral therapy; Human immunodeficiency virus; Infection; Mother-to-child-transmission; Perinatal infection; Prevention

Abbreviations: ARV: Antiretroviral Drugs; cART: Combination Antiretroviral Therapy; CDC: Centers for Disease Control and Prevention; DNA: Deoxyribonucleic acid; EIA: Enzyme Immunoassay; MIRIAD: Mother-Infant Rapid Intervention at Delivery Study; MTCT: Mother-to-Child Transmission; PCR: Polymerase Chain Reaction; PBMCs: Peripheral Blood Mononuclear Cells; RNA: Ribonucleic acid; ZDV: Zidovudine

\section{Introduction}

In 1994, it was demonstrated that the administration of zidovudine (ZDV) to the HIV-infected pregnant woman during her second and third trimesters and to her newborn reduced the rate of mother-tochild transmission (MTCT) of HIV by two-thirds [1]. ZDV can reduce the rate of MTCT even when initiated as late as 36 weeks gestation [2]. The use of combination antiretroviral therapy during pregnancy and delivery has reduced the rate of MTCT to $2 \%$ or less [3-5]. Of the fewer than 150 infants who are estimated to acquire perinatal HIV in the US each year, approximately one-third are born to mothers with unknown HIV status and therefore could not benefit from interventions to prevent MTCT [6-8].
Rapid HIV testing late in pregnancy or at delivery provides a final opportunity (among non-breast-feeding mothers) to diagnose HIV and prevent MTCT. Antiretroviral drugs (ARV) administered to the woman during labor and to her infant following delivery can reduce the risk of MTCT [9]. Even when administered only to the infant following delivery, ARVs can reduce the rate of MTCT [10,11]. The Mother-Infant Rapid Intervention at Delivery (MIRIAD) Study was a Center for Disease Control and Prevention (CDC)-funded multi-site study to evaluate the feasibility and acceptability of rapid HIV testing in late pregnancy or during labor among pregnant women with unknown

*Corresponding author: Russell B Van Dyke, Department of Pediatrics, TB-8 Tulane University School of Medicine, 1430 Tulane Ave, New Orleans, LA, USA, 70114, Tel: 504-988-2570; Fax: 504-988-3805; E-mail: vandyke@tulane.edu

Received May 04, 2014; Accepted June 25, 2015; Published July 05, 2015

Citation: Van Dyke RB, Danner SP, Chrestman S, Kissinger P, Nesheim S, et al (2015) Outcomes of Infants Born to HIV-Infected Women Identified by Rapid HIV Testing Late in Pregnancy or at Delivery: The MIRIAD Study. J AIDS Clin Res 6 : 484. doi:10.4172/2155-6113.1000484

Copyright: () 2015 Van Dyke RB, et al. This is an open-access article distributed under the terms of the Creative Commons Attribution License, which permits unrestricted use, distribution, and reproduction in any medium, provided the original author and source are credited. 
HIV status. The intervention has been described previously $[12,13]$. We now present the infection status of the infants and explore factors associated with MTCT.

\section{Materials and Methods}

\section{Study procedures}

The MIRIAD study was conducted between November 2001 and February 2005 at 17 hospitals in six cities in the US. Pregnant women were eligible for enrollment if their HIV infection status during the current pregnancy was not documented in their medical record and: (1) they first presented for prenatal care at or beyond 34 weeks gestation but before the onset of labor (the Late Presenting Group); or (2) they presented in labor at or beyond 24 weeks gestation (the Peripartum Group). The protocol was approved by the Institutional Review Boards of the CDC and participating institutions and written informed consent was obtained from each participant. Participants were offered HIV counseling and voluntary rapid HIV testing. Sites were encouraged to retest women in the third trimester if they had a negative test earlier in the pregnancy and those with a positive test were eligible for enrollment into the Late Presenting Group. Further details of the study and results of maternal HIV testing have been reported previously [12,13]. This analysis focuses on the HIV-exposed infants born to the women found to be HIV-infected. The HIV-infected pregnant women and their infants were managed according to the local standard of care, including the administration of ARV for prevention of MTCT. The maternal and infant medical histories were abstracted from the medical record and recorded on standardized forms. Combination antiretroviral therapy (cART) was defined as at least three ARV drugs from at least two classes.

\section{Maternal evaluations}

The enrolled women were evaluated at study entry, 2 weeks postentry (if still pregnant), during labor and delivery, and at specified intervals until 24 month following delivery. At specified visits, plasma RNA viral load and lymphocyte subsets were determined. Peripheral blood mononuclear cells (PBMCs) and plasma were stored at $-70^{\circ} \mathrm{C}$. Vaginal swabs were collected at entry, 2 weeks post-entry if still pregnant, and during labor. Vaginal secretions were eluted from the swab and cell and supernatant fractions were stored separately at $-70^{\circ} \mathrm{C}$. The HIV viral load of the vaginal secretions was performed as previously described [14]. Cord blood was collected at delivery after thorough cleaning of the cord surface and the plasma was stored at $-70^{\circ} \mathrm{C}$. For women undergoing Cesarean delivery, amniotic fluid was collected by aspiration and frozen at $-70^{\circ} \mathrm{C}$.

\section{Infant evaluations}

The infants were evaluated at the following ages: 0-48 hours, 2 weeks, 4 weeks, 6 weeks, 3 months, 6 months, and then every 3 months for infected infants and every 6 months for uninfected infants until 24 months of age. The HIV-1 infection status of the infants was determined by the presence of HIV-1 DNA in PBMCs or plasma RNA from blood collected prior to 48 hours of age, at 2, 4, and 6 weeks of age and at each subsequent visit until the infection status of the infant was determined. Infants were defined as HIV-infected if 2 separate blood specimens drawn on different days were both positive for HIV DNA or RNA (>10,000 copies/mL) [15]. Cord blood was not used to define infant infection status. An infected infant was further classified as having an in utero infection if a blood sample obtained within 48 hours of birth was positive for HIV DNA or RNA. An infected infant was classified as having an intrapartum infection if a blood sample collected within 7 days of birth was negative for HIV DNA or RNA [16]. An infected child who did not have a blood sample available within 7 days of birth had undefined timing of transmission. A child was defined as HIV-uninfected if the child had never breast fed and had 2 blood samples which were negative for HIV-1 DNA or RNA, one of which was collected when the child was at least 6 weeks of age. In addition, an uninfected child could not have any test indicating the presence of HIV (e.g., culture, p24 antigen, or DNA or RNA PCR). A child who failed to meet these definitions was considered to be of indeterminate HIV infection status.

\section{Viral sequence analysis}

The sequence of the V3 region of the HIV envelope gene from reverse-transcribed cell-free virus or PMBC genomic DNA was determined as previously described [14]. Viral diversity was determined by comparing viral sequences from maternal and infant samples using MacVector, version 7.2.3 (Accelrys, San Diego, CA).

\section{Data analysis}

Data analysis was conducted using SPSS statistical software. Data was tabulated and presented as proportions, medians, and ranges.

\section{Results}

Fifty-four HIV-infected pregnant women were identified, of whom 50, and their 51 infants, were eligible for this analysis (Figure 1). Of the 4 women who were not eligible, 2 were lost to follow-up prior to delivery, 1 did not have rapid testing and was not tested until 5 days after delivery, and 1 was found to be infected 1 month following delivery. Both infants born to the 2 mothers excluded from this analysis but not lost to follow-up prior to delivery were confirmed to be uninfected. Of the 50 eligible women, 11 were in the Late Presenting Group and 39 in the Peripartum Group (Figure 1, Table 1). Four women in the Peripartum Group had a documented primary HIV infection during the pregnancy; 1 was among the 4 ineligible women.

\section{Late presenting group (Table 1)}

Nine of the 11 women in the Late Presenting group had ARV data; 5 received prenatal ARV and 9 received intrapartum ARV. All 9 infants with ARV data received preventive ARVs following delivery and all 11 infants were confirmed to be uninfected.

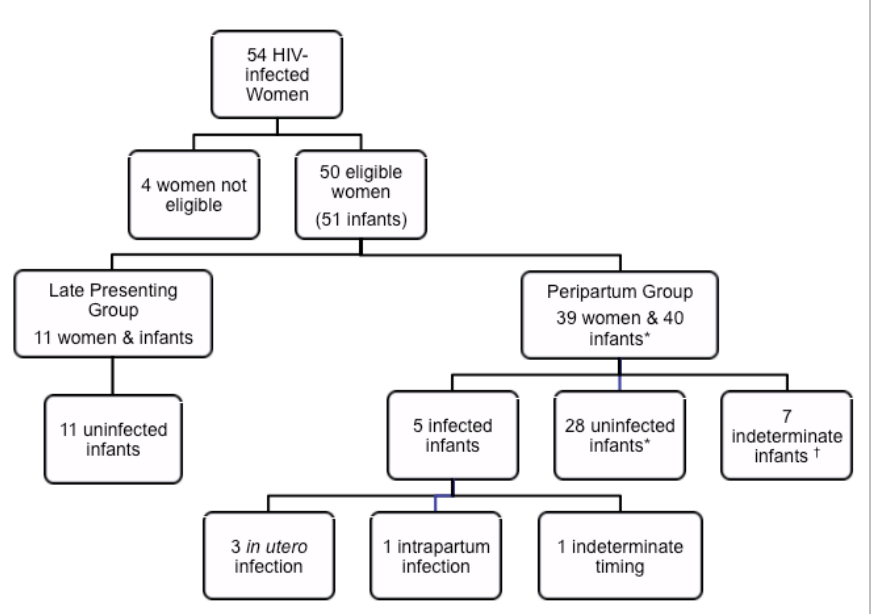

* Includes one set of twins

† in utero infection excluded in 6 infants

Figure 1: MIRIAD Study 2001-2005: derivation and outcomes of the HIVinfected women and their infants. 
Citation: Van Dyke RB, Danner SP, Chrestman S, Kissinger P, Nesheim S, et al. (2015) Outcomes of Infants Born to HIV-Infected Women Identified by Rapid HIV Testing Late in Pregnancy or at Delivery: The MIRIAD Study. J AIDS Clin Res 6: 484. doi:10.4172/2155-6113.1000484

Page 3 of 7

\section{Peripartum group (Table 1)}

Three of the 39 women in the Peripartum Group had premature labor that was stopped, allowing them to receive prenatal ARV, and 25 received intrapartum ARV. Of the 14 women who did not receive intrapartum ARV, 9 were identified as being HIV-infected postpartum, 1 delivered at home, and 4 delivered before they were able to receive ARVs. One woman delivered twins.

All 40 infants in the Peripartum Group received preventive ARV following delivery. Thirty-three infants had a confirmed infection status with $5(15 \%)$ infected and 28 (85\%) uninfected (including both twins). (Table 2) Of the 3 infants born to a mother with a documented primary HIV infection during the pregnancy, 1 (infant B, Table 2) was infected. Three infected infants (A, B and C) had in utero transmission, 1 (D) had intrapartum transmission, and 1 (E) had indeterminate timing of transmission.
All 7 infants with an indeterminate HIV infection status were lost to follow-up prior to 6 weeks of age and intrapartum infection could not be excluded. However, 6 had negative PCR results which ruled-out in utero infection ( 5 at $\leq 48$ hours and 1 at 8 days of age). The seventh infant had no PCR testing.

\section{Characteristics of infants with defined infection status and their mothers (Table 3)}

Overall, 44 infants had adequate samples to determine their infection status and five were infected $(11.4 \%, 95 \%$ confidence interval 1.9 - 20.7). Details of infants A-C have been published previously [14]. Selected clinical and demographic characteristics of the infected and uninfected infants and their mothers, including risk factors for MTCT, are presented in Table 3. The majority of mothers were AfricanAmerican; 58\% received no prenatal care, most delivered at term and $42 \%$ had a Cesarean delivery. Eighteen percent of the mothers received

\begin{tabular}{|c|c|c|c|}
\hline & Late Presenting Group, $\mathbf{n}(\%)$ & Peripartum Group, n (\%) & Total, $\mathbf{n}(\%)$ \\
\hline Women & 11 * & 39 * & 50 * \\
\hline $\begin{array}{l}\text { Prenatal ARV } \\
\text { cART }\end{array}$ & $\begin{array}{l}5 / 9(56 \%) \\
3 / 5(60 \%)\end{array}$ & $\begin{array}{l}3 / 38(8 \%) \\
2 / 3(67 \%)\end{array}$ & $\begin{array}{c}8 / 47(17 \%) \\
5 / 8(63 \%)\end{array}$ \\
\hline Intrapartum ARV & 9/9 (100\%) & $25 / 39(64 \%)$ & $34 / 48(71 \%)$ \\
\hline Cesarean section & $6 / 11(55 \%)$ & $14 / 39(36 \%)$ & $20 / 50(36 \%)$ \\
\hline Infants & 11 * & $40 * \dagger$ & $51 * \dagger$ \\
\hline Infant ARV & $9 / 9(100 \%)$ & $40 / 40(100 \%)$ & $49 / 49(100 \%)$ \\
\hline Infected infants $\ddagger$ & $0 / 11(0 \%)$ & $5 / 33(15 \%)$ & $5 / 44(11 \%)$ \\
\hline
\end{tabular}

ARV: Antiretroviral; cART: Combination Antiretroviral Therapy

* Denominator changes due to missing data

† 1 set of twins in Peripartum Group, both confirmed to be uninfected

$\ddagger$ Among 44 infants with defined infection status

Table 1: Maternal and infant antiretroviral and infant infection status by study group, MIRIAD Study, 2001-2005.

\begin{tabular}{|c|c|c|c|c|c|}
\hline & \multicolumn{5}{|c|}{ Mother/Infant Pair } \\
\hline & A & B * & $\mathbf{C}$ & D & $\mathbf{E}$ \\
\hline \multicolumn{6}{|l|}{ Mother } \\
\hline Timing of HIV diagnosis (hours before delivery) & 5 & 4 & 2.3 & 9 & Post-partum \\
\hline Prenatal ARV & none & none & none & none & none \\
\hline Intrapartum ARV & ZDV & ZDV, NVP & ZDV, NVP & ZDV & none \\
\hline $\begin{array}{l}\text { VL closest to delivery (copies } / \mathrm{mL} \text { ) } \\
\text { (days following delivery) }\end{array}$ & $\begin{array}{c}8,140 \\
(0)\end{array}$ & $\begin{array}{c}2,630 \\
(0)\end{array}$ & $\begin{array}{l}10,100 \\
(0)\end{array}$ & $\begin{array}{c}44,600 \\
(19)\end{array}$ & $\begin{array}{c}18,947 \\
(1)\end{array}$ \\
\hline $\begin{array}{l}\text { CD4 count closest to delivery (cells/ } \mu \mathrm{L} \text { ) } \\
\text { (days following delivery) }\end{array}$ & $\begin{array}{c}241 \\
(0)\end{array}$ & $\begin{array}{l}289 \\
(0)\end{array}$ & $\begin{array}{l}141 \\
(3)\end{array}$ & $\begin{array}{l}163 \\
(19)\end{array}$ & $\begin{array}{c}758 \\
(1)\end{array}$ \\
\hline Duration of ruptured membranes (hours) & 6.1 & NA & 7.9 & 16.2 & 0.1 \\
\hline Delivery Mode & Vaginal & Cesarean & Vaginal & Vaginal & Vaginal \\
\hline Vaginal VL closest to delivery (copies/mL) & 50 & 2,580 & 1,660 & $342 \dagger$ & NA \\
\hline Number of Sexually Transmitted Infections recorded during pregnancy & 4 & NA & NA & 1 & 0 \\
\hline Substance use at delivery $\ddagger$ & negative & NA & cocaine & negative & NA \\
\hline \multicolumn{6}{|l|}{ Infant } \\
\hline Sex & M & $\mathrm{F}$ & M & $\mathrm{F}$ & M \\
\hline Gestational age (weeks) & 40 & NA & 36 & 38 & 36 \\
\hline Preventive ARV & ZDV & ZDV, SD-NVP & ZDV, SD-NVP & ZDV, SD-NVP & ZDV \\
\hline Cord Blood VL (RNA copies/ mL) & 465 & NA & 12,000 & $<50 \S$ & NA \\
\hline First positive DNA PCR (day of life) & 1 & 1 & 1 & 48 & $16 \#$ \\
\hline Timing of transmission & in utero & in utero & in utero & Intrapartum \& & Indeterminate \# \\
\hline
\end{tabular}

NA: Not Available; Date of life: Day of birth is day 1; VL: HIV Viral Load; ARV: Antiretroviral

${ }^{*}$ Mother had a documented primary HIV infection during pregnancy

† From day 5 post-partum

$\ddagger$ Urine screen on mother and/or infant

$\S$ Below lower limit of detection

\# No newborn testing. Also positive plasma HIV RNA (2392 copies $/ \mathrm{mL}$ ) on day 16 of life

\& Negative HIV DNA testing on days 1 and 18 of life

Table 2: Clinical characteristics of the 5 HIV-infected infants and their mothers, MIRIAD Study, 2001-2005. 
Citation: Van Dyke RB, Danner SP, Chrestman S, Kissinger P, Nesheim S, et al. (2015) Outcomes of Infants Born to HIV-Infected Women Identified by Rapid HIV Testing Late in Pregnancy or at Delivery: The MIRIAD Study. J AIDS Clin Res 6: 484. doi:10.4172/2155-6113.1000484

Page 4 of 7

\begin{tabular}{|c|c|c|}
\hline & Uninfected infants $\dagger$ & $\begin{array}{l}\text { Infected } \\
\text { Infants }\end{array}$ \\
\hline MOTHERS $(n=43)$ & $\mathbf{n}=38 \ddagger$ & $\mathbf{n}=\mathbf{5} \ddagger$ \\
\hline Age (median, range) & $26(16-41)$ & $25(23-45)$ \\
\hline $\begin{array}{l}\text { Race / Ethnicity } \\
\text { Black/African American, n (\%) } \\
\text { White, not Hispanic, n (\%) } \\
\text { Hispanic, n (\%) } \\
\text { Unknown, n (\%) }\end{array}$ & $\begin{array}{c}33(87 \%) \\
2(5 \%) \\
3(8 \%) \\
0\end{array}$ & $\begin{array}{c}4(80 \%) \\
0 \\
0 \\
1(20 \%)\end{array}$ \\
\hline $\begin{array}{l}\text { Self-reported substance use during pregnancy } \\
\text { Alcohol, } \mathrm{n}(\%) \\
\text { Marijuana, } \mathrm{n}(\%) \\
\text { Cocaine or heroin, } \mathrm{n}(\%)\end{array}$ & $\begin{array}{l}4 / 33(12 \%) \\
5 / 33(15 \%) \\
7 / 34(21 \%)\end{array}$ & $\begin{array}{c}0 / 3 \\
0 / 3 \\
1(20 \%)\end{array}$ \\
\hline $\begin{array}{l}\text { Substance use testing at delivery, } \mathrm{n}(\%) \\
\text { Cocaine, } \mathrm{n}(\%) \\
\text { Cocaine and marijuana, } \mathrm{n}(\%) \\
\text { Opiates and barbiturates, } \mathrm{n}(\%)\end{array}$ & $\begin{array}{c}5 / 21(24 \%) \\
4 / 21(19 \%) \\
1 / 21(5 \%)\end{array}$ & $\begin{array}{l}1 / 3(33 \%) \\
0 / 3 \\
0 / 3\end{array}$ \\
\hline STI during pregnancy, $\mathrm{n}(\%)$ & $8 / 33(24 \%)$ & $2 / 3(66 \%)$ \\
\hline New sex partners during pregnancy, n (\%) & $1 / 33(3.0 \%)$ & 0 \\
\hline Primary HIV infection during pregnancy, n (\%) & $2(5.3 \%)$ & $1(20 \%)$ \\
\hline No prenatal care, n (\%) & $20 / 36(56 \%)$ & $2 / 2(100 \%)$ \\
\hline $\begin{array}{l}\text { Prenatal ARV, n (\%) } \\
\text { cART, n (\%) }\end{array}$ & $\begin{array}{l}7 / 35(20 \%) \\
4 / 7(57 \%)\end{array}$ & $\begin{array}{l}0 \\
0\end{array}$ \\
\hline Intrapartum ARV, n (\%) & $23 / 34(68 \%)$ & $4(80 \%)$ \\
\hline $\begin{array}{l}\text { CD4 count closest to delivery } \\
\text { Median (cells } / \mathrm{mm}^{3}, \text { range) } \\
<200 \text { cells } / \mathrm{mm}^{3}, \mathrm{n}(\%) \\
200-349 \text { cells } / \mathrm{mm}^{3}, \mathrm{n}(\%) \\
\geq 350 \text { cells } / \mathrm{mm}^{3}, \mathrm{n}(\%)\end{array}$ & $\begin{array}{c}315(77-1849) \\
4 / 26(15 \%) \\
11 / 26(42 \%) \\
11 / 26(42 \%)\end{array}$ & $\begin{array}{l}241(141-758) \\
\quad 2(40 \%) \\
2(40 \%) \\
1(20 \%)\end{array}$ \\
\hline Viral load (copies/mL) at delivery (median, range) & $\begin{array}{c}11,032 \\
(<50-66,300) \\
(n=22)\end{array}$ & $\begin{array}{c}45,263 \\
(18,947-287,000) \\
(n=4)\end{array}$ \\
\hline $\begin{array}{l}\text { Rupture of membranes prior to delivery, } n(\%) \\
\text { Rupture of membranes }>4 \text { hours, } n(\%)\end{array}$ & $\begin{array}{l}14 / 34(41 \%) \\
9 / 31(29 \%)\end{array}$ & $\begin{array}{l}3 / 4(75 \%) \\
3 / 4(75 \%)\end{array}$ \\
\hline $\begin{array}{l}\text { Delivery Mode } \\
\text { Vaginal, n (\%) } \\
\text { Cesarean, n (\%) }\end{array}$ & $\begin{array}{l}21(55 \%) \\
17(45 \%)\end{array}$ & $\begin{array}{l}4(80 \%) \\
1(20 \%)\end{array}$ \\
\hline $\begin{array}{l}\text { Procedure during labor, } \mathrm{n}(\%) \\
\text { Fetal scalp electrode, } \mathrm{n}(\%) \\
\text { Fetal pulse oximetry, } \mathrm{n}(\%) \\
\text { Intrauterine catheter, } \mathrm{n}(\%)\end{array}$ & $\begin{array}{l}3 / 37(8 \%) \\
1 / 37(3 \%) \\
1 / 37(3 \%) \\
1 / 37(3 \%)\end{array}$ & $\begin{array}{c}1 / 4(25 \%) \\
1 / 4(25 \%) \\
0 \\
0\end{array}$ \\
\hline Maternal Intrapartum ARV, n (\%) & $23 / 34(68 \%)$ & $4(80 \%)$ \\
\hline Breast feed, n (\%) & $0 / 36$ & 0 \\
\hline INFANTS ( $\mathrm{N}=44)$ & $\mathbf{N}=39 \ddagger$ & $\mathbf{N}=\mathbf{5} \ddagger$ \\
\hline Male sex, $\mathrm{n}(\%)$ & $17 / 36(47 \%)$ & $3(60 \%)$ \\
\hline Median Gestational Age in weeks (range) & $\begin{array}{l}38(27-41) \\
(n=38)\end{array}$ & $\begin{array}{l}38(36-40) \\
(n=4)\end{array}$ \\
\hline Infant Postnatal ARV, n (\%) & $37 / 37(100 \%)$ & $5(100 \%)$ \\
\hline Duration of follow-up in months (median, range) & $\begin{array}{l}12(6-30) \\
(n=33)\end{array}$ & $24(6-30)$ \\
\hline
\end{tabular}

STI: Sexually Transmitted Infections; ARV: Antiretrovirals; cART: Combination Antiretroviral Therapy

*Excludes 7 mother-infant pairs where infant is of indeterminate infection status

$\dagger$ Includes one set of twins

$\mp N$ is total group unless otherwise indicated. Denominator changes due to missing data

Table 3: Selected characteristics of the 44 infants with confirmed infection status and their mothers, MIRIAD Study, 2001-2005.*

prenatal ARV and 69\% received intrapartum ARV. All of the infants received preventive ARV in the newborn period. The mothers of the infected infants, as compared to those of uninfected infants, had a lower median CD4 cell count and a higher median HIV plasma viral load around delivery; a greater proportion had membranes ruptured for more than four hours, had a vaginal delivery, and had a sexually transmitted infection during the pregnancy. The rates of substance use were similar in the two groups.

\section{Comparison of viral sequences of infected infants and their mothers (Table 2)}

The mother of infant A (in utero transmission) had detectable HIV RNA in plasma and vaginal fluid at delivery and her infant had detectible viral RNA in cord blood ( 465 copies $/ \mathrm{mL}$ ) and a positive blood DNA PCR at 1 day of age. No amniotic fluid was collected. The V3 amino acid sequences of viruses from baby's plasma were highly similar and were identical to those found in maternal vaginal fluid. 
Viral sequences in maternal blood were similar to those found in the infant and vaginal fluid, but varied by up to $6 \%$ [14].

The mother of infant B (in utero transmission) had a documented primary HIV infection during pregnancy. She had detectable HIV in plasma, vaginal fluid, and amniotic fluid $(50$ copies $/ \mathrm{mL})$ at delivery. The viral sequences in infant plasma collected one month after birth were identical to those found in amniotic fluid as well as to the proviral DNA sequences found in maternal PBMC DNA at delivery. Viral sequences in maternal plasma and vaginal secretions were more diverse, but contained genotypes highly similar to those found in the infant $(3-5 \%$ divergent). [14].

The mother of infant C (in utero transmission) had detectable HIV in plasma and vaginal fluid at delivery. Her infant had detectible viral RNA in cord blood (12,000 copies/mL) and DNA in blood obtained at 1 day of age. By sequencing, two virus genotypes were found in both cord blood and the infant's plasma (obtained at 4 weeks of age) that differed by $33 \%$ over the V3 region that was analyzed. One infant genotype was identical to the predominant viral sequences in maternal plasma and vaginal secretions at the time of delivery. The second infant genotype was identical to proviral DNA sequences amplified from the mother's $\mathrm{PBMC}$ at the time of delivery [14].

The mother of infant $\mathrm{D}$ (intrapartum transmission) had detectible HIV in vaginal fluid five days post-partum and a plasma viral load of 44,600 copies/mL 19 days post-partum. Her infant had a fetal scalp electrode applied during labor and a vaginal delivery following 16.2 hours of ruptured membranes, both risk factors for intrapartum transmission. The infant had no detectible HIV RNA in cord blood $(<50$ copies $/ \mathrm{mL}$ ) and HIV DNA PCR testing of blood was negative on days 1 and 19 and positive on day 48 of life. By sequencing, the viruses from vaginal fluid were highly divergent over the V3 region (36\% diversity) from those found in baby's plasma on day 48 . No maternal plasma virus was available for sequencing.

The mother of infant $\mathrm{E}$ (indeterminate timing of transmission) was found to be infected following delivery and had no intrapartum samples. Her infant had a first DNA PCR test positive on day 16 of life; no blood samples were available prior to day 16 . On day 23 , the child had detectible HIV RNA in plasma (2,350 copies/mL). The V3 amino acid sequence of the virus from the infant's plasma at 23 days of age was identical to that found in maternal plasma obtained at 55 days after delivery.

\section{Discussion}

The MIRIAD study confirms the feasibility and effectiveness of rapid HIV testing late in pregnancy to identify HIV-infected women, allowing for the initiation ARV for PMTCT. We were able to administer preventive ARV to $71 \%$ of all infected pregnant women prior to delivery and to all of their infants with available data. Among the Late Presenting group who were tested prior to the onset of labor, all of the infected mothers and their infants with available data received preventive ARV and no mother transmitted HIV to her infant.

Among the Peripartum Group, rapid testing following the onset of labor allowed $64 \%$ of the infected mothers and all of their infants to receive preventive ARV, resulted in a MTCT rate of $15 \%$ (Table 1). This rate is similar to that of $11.8 \%$ observed in the Uganda HIVNET 012 trial, in which SD-NVP was administered to women following onset of labor and their infants, supporting the value of rapid testing following the onset of labor [17]. Even when administered only to the exposed infant following delivery, ARVs can reduce the rate of MTCT [10]. A study conducted in Brazil and South Africa (HPTN 040) demonstrated that among infants born to HIV-infected mothers who did not receive $\mathrm{ARV}$, postpartum combination ARV is significantly more effective than ZDV alone in preventing intrapartum transmission [11]. Thus, rapid testing of women of unknown HIV status during labor affords a final opportunity to reduce the risk of MTCT.

In the absence of breast feeding and preventive ARV, among infants ultimately shown to be infected, approximately one-third have in utero transmission, defined as having virus detected within the first 48 hours of life $[16,18]$. The remaining two-thirds of infected infants have virus first detectible at 4-6 weeks of life and are believed to have intrapartum transmission through exposure to maternal blood and secretions during labor and delivery. It is likely that most in utero transmission occur late in pregnancy, explaining why infected infants rarely have clinical abnormalities or suppressed CD4+ lymphocyte counts at birth [19]. Maternal prenatal combination ARV, as currently recommended to prevent MTCT, will prevent both in utero and intrapartum transmission $[18,20]$. However, interventions initiated near delivery, such as an elective Cesarean delivery or intrapartum ARV, can only be expected to prevent intrapartum transmission.

Fifty of the 51 infants (excluding only infected infant E) had samples necessary to identify an in utero infection - either uninfected or infected with a sample obtained at $\leq 48$ hours of age - and 3 had a confirmed in utero infections, giving an in utero transmission rate of $6.0 \%(3 / 50)$ overall and $7.7 \%$ (3/39) among those in the Peripartum Group. These rates are similar to the in utero transmission rates reported prior to the use of prenatal ARV $[9,21]$. This is expected since, in the absence of prenatal ARV, ARV administered during labor cannot be expected to interrupt in utero transmission.

Among the 44 infants with defined infection status (excluding the 7 with indeterminate infection status and assuming that infant $\mathrm{E}$ had intrapartum transmission), the upper estimate of the overall intrapartum transmission rate is $4.5 \%$ (2/44, including the three infants with in utero transmission) and 6.1\% (2/33) among those in the Peripartum Group. This intrapartum transmission rate is similar to that found in studies that administered only maternal intrapartum and newborn ARV and is substantially lower than that observed without ARV prophylaxis [18,22-26].

Comparison of the viral sequences of maternal and infant viruses can help elucidate the mechanism of MTCT [14]. Infant viral sequences were closely related or identical to those of mother's virus in four of the five mother/infant pairs. In pair $\mathrm{C}$, the infant was infected with two distinct viral genotypes, each corresponding to virus present in different maternal compartments. This suggests that the infant was infected with two distinct maternal viruses [14]. In pair D, maternal virus from vaginal fluid obtained after delivery differed from that present in her infant's blood, suggesting that, despite intrapartum transmission, the infant was infected by a virus present in a different maternal compartment than the vagina. Although all mothers were advised against breast feeding, transmission by breast feeding cannot be definitively excluded for infant $\mathrm{D}$.

The five transmitting mothers, when compared to non-transmitting mothers, exhibited several of the known risk factors for MTCT, including a low CD4+ count and elevated plasma viral load at delivery, a vaginal rather than a Cesarean delivery, prolonged rupture of membranes, no prenatal ARV, and in one case, a fetal scalp electrode [1,9,27-31]. Because of the small number of infected infants, a formal analysis of risk factors for transmission could not be conducted. 
Citation: Van Dyke RB, Danner SP, Chrestman S, Kissinger P, Nesheim S, et al. (2015) Outcomes of Infants Born to HIV-Infected Women Identified by Rapid HIV Testing Late in Pregnancy or at Delivery: The MIRIAD Study. J AIDS Clin Res 6: 484. doi:10.4172/2155-6113.1000484

Limitations of the study include missing data, a small number of infected infants, and use of a convenience sample of clinical sites, which may limit the generalizability of the results. However, the sites are experienced in providing HIV care and have access to large numbers of HIV-infected women. Finally, the estimated rates of MTCT would be misleading if the 7 infants with indeterminate infection status were not representative of the total group.

\section{Conclusions}

Rapid HIV testing of women of unknown HIV status late in pregnancy or during labor, with the administration of ARV to infected women, has little effect on in utero transmission of HIV but is effective in reducing intrapartum transmission. This highlights the importance of establishing systems to ensure that all women of unknown HIV status are offered HIV testing during pregnancy, including those in labor, so that effective PMTCT regimens can be initiated [32]. Even when performed after the onset of labor, rapid testing allows for the administration of ARV which will reduce the risk of intrapartum MTCT. These findings also support the importance of repeat HIV testing late in pregnancy for women who tested negative earlier in the pregnancy, as is currently recommended if at increased risk of HIV infection [33].

\section{Acknowledgements}

Source of funding: The MIRIAD study was coordinated and funded by the National Center for HIV, Viral Hepatitis, STD and TB Prevention at the CDC under cooperative agreements U64/217724, U64/417719, U64/417735, U64/517715, and U64/617734.

The findings and conclusions of this report are those of the authors and do not necessarily represent the views of the Centers for Disease Control and Prevention.

We thank all the study participants, the MIRIAD site investigators and the many people who provided critical input into protocol development, training at the sites and guidance and support throughout the duration of the study. Dr. Alan Greenberg (CDC) provided scientific guidance and support throughout the study. We especially thank Margaret Lampe, RN, MPH, Rosalind Carter, PhD, Yolanda Olszewski, PhD, MPH, Renata Dennis, RN, MPH, Robert Maupin, MD, Mary Jo O'Sullivan, MD, Mayris Webber, DrPH, Bernard Branson, MD, Michael Lindsay, MD, MPH, Francis Lee, PhD, Pat Garcia, MD, Erin Curtin, PhD, Sivakumar Rangarajan, and Sanjyot Shinde, PhD, for their contributions to the MIRIAD study.

\section{References}

1. Connor EM, Sperling RS, Gelber R, Kiselev P, Scott G, et al. (1994) Reduction of maternal-infant transmission of human immunodeficiency virus type 1 with zidovudine treatment. N Engl J Med 331:1173-1180.

2. Shaffer N, Chuachoowong R, Mock PA, Bhadrakom C, Siriwasin W, et al. (1999) Short-course zidovudine for perinatal HIV-1 transmission in Bangkok, Thailand: a randomised controlled trial. Lancet 353:773-780.

3. Cooper ER, Charurat M, Mofenson L, Hanson IC, Pitt J, et al. (2002) Combination antiretroviral strategies for the treatment of pregnant HIV-1infected women and prevention of perinatal HIV-1 transmission. J Acquir Immune Defic Syndr 29: 484-494.

4. Ioannidis JP, Abrams EJ, Ammann A, Bulterys M, Goedert JJ, et al. (2001) Perinatal transmission of human immunodeficiency virus type 1 by pregnant women with RNA virus loads <1000 copies/ml. J Infect Dis 183: 539-545.

5. Birkhead GS, Pulver WP, Warren BL, Hackel S, Rodriguez D, et al. (2010) Acquiring human immunodeficiency virus during pregnancy and mother-tochild transmission in New York: 2002-2006. Obstet Gynecol 115:1247-1255.

6. McKenna MT, Hu X (2007) Recent trends in the incidence and morbidity that are associated with perinatal human immunodeficiency virus infection in the United States. Am J Obstet Gynecol 197: S10-16.

7. Whitmore SK, Taylor AW, Espinoza L, Shouse RL, Lampe MA, et al. (2012) Correlates of mother-to-child transmission of HIV in the United States and Puerto Rico. Pediatrics 129: e74-81.

8. Centers for Disease Control and Prevention, Mofenson L, Taylor A, Rogers M, Campsmith M, et al. (2006) Achievements in public health. Reduction in perinatal transmission of HIV infection--United States, 1985-2005. MMWR Morb Mortal Wkly Rep 55: 592-597.
9. Guay LA, Musoke P, Fleming T, Bagenda D, Allen M, et al. (1999) Intrapartum and neonatal single-dose nevirapine compared with zidovudine for prevention of mother-to-child transmission of HIV-1 in Kampala, Uganda: HIVNET 012 randomised trial. Lancet 354: 795-802.

10. Wade NA, Birkhead GS, Warren BL, Charbonneau TT, French PT, et al. (1998) Abbreviated regimens of zidovudine prophylaxis and perinatal transmission of the human immunodeficiency virus. N Engl J Med 339:1409-1414.

11. Nielsen-Saines K, Watts DH, Veloso VG, Bryson YJ, Joao EC, et al. (2012) Three postpartum antiretroviral regimens to prevent intrapartum HIV infection. N Engl J Med 366:2368-2379.

12. Bulterys M, Jamieson DJ, O'Sullivan MJ, Cohen MH, Maupin R, et al. (2004) Rapid HIV-1 testing during labor: a multicenter study. JAMA 292: 219-223.

13. Jamieson DJ, Cohen MH, Maupin R, Nesheim S, Danner SP, et al. (2007) Rapid human immunodeficiency virus-1 testing on labor and delivery in 17 US hospitals: the MIRIAD experience. Am J Obstet Gynecol 197: S72-82.

14. Kourtis AP, Amedee AM, Bulterys M, Danner S, Van Dyke R, et al. (2011) Various viral compartments in HIV-1-infected mothers contribute to in utero transmission of HIV-1. AIDS Res Hum Retroviruses 27: 421-427.

15. Panel on Antiretroviral Therapy and Medical Management of HIV-Infected Children (2015) Guidelines for the Use of Antiretroviral Agents in Pediatric HIV Infection.

16. Bryson YJ, Luzuriaga K, Sullivan JL, Wara DW (1992) Proposed definitions for in utero versus intrapartum transmission of HIV-1. N Engl J Med 327: 12461247.

17. Jackson JB, Musoke P, Fleming T, Guay LA, Bagenda D, et al. (2003) Intrapartum and neonatal single-dose nevirapine compared with zidovudine for prevention of mother-to-child transmission of HIV-1 in Kampala, Uganda: 18-month follow-up of the HIVNET 012 randomised trial. Lancet 362: 859-868.

18. Magder LS, Mofenson L, Paul ME, Zorrilla CD, Blattner WA, et al. (2005) Risk factors for in utero and intrapartum transmission of HIV. J Acquir Immune Defic Syndr 38:87-95. (http://www.ncbi.nlm.nih.gov/pubmed/15608531)

19. Kourtis AP, Lee FK, Abrams EJ, Jamieson DJ, Bulterys M (2006) Mother-tochild transmission of HIV-1: timing and implications for prevention. Lancet Infect Dis 6: 726-732.

20. Panel on Treatment of HIV-Infected Pregnant Women and Prevention of Perinatal Transmission (2014) Recommendations for Use of Antiretroviral Drugs in Pregnant HIV-1-Infected Women for Maternal Health and Interventions to Reduce Perinatal HIV Transmission in the United States 2014.

21. Chasela CS, Hudgens MG, Jamieson DJ, Kayira D, Hosseinipour MC, et al (2010) Maternal or infant antiretroviral drugs to reduce HIV-1 transmission. N Engl J Med 362: 2271-2281.

22. Taha TE, Kumwenda NI, Gibbons A, Broadhead RL, Fiscus S, et al. (2003) Short postexposure prophylaxis in newborn babies to reduce mother-to-child transmission of HIV-1: NVAZ randomised clinical trial. Lancet 362: 1171-1177.

23. Taha TE, Kumwenda NI, Hoover DR, Fiscus SA, Kafulafula G, et al. (2004) Nevirapine and zidovudine at birth to reduce perinatal transmission of HIV in an African setting: a randomized controlled trial. JAMA 292: 202-209.

24. Moodley D, Moodley J, Coovadia H, Gray G, Mclntyre J, et al. (2003) A multicenter randomized controlled trial of nevirapine versus a combination of zidovudine and lamivudine to reduce intrapartum and early postpartum motherto-child transmission of human immunodeficiency virus type 1 . J Infect Dis 187: 725-735.

25. Petra Study Team (2002) Efficacy of three short-course regimens of zidovudine and lamivudine in preventing early and late transmission of HIV-1 from mother to child in Tanzania, South Africa, and Uganda (Petra study): a randomised, double-blind, placebo-controlled trial. Lancet 359: 1178-1186.

26. Leroy V, Sakarovitch C, Cortina-Borja M, McIntyre J, Coovadia H, et al. (2005) Is there a difference in the efficacy of peripartum antiretroviral regimens in reducing mother-to-child transmission of HIV in Africa? AIDS 19: 1865-1875.

27. Garcia PM, Kalish LA, Pitt J, Minkoff H, Quinn TC, et al. (1999) Maternal levels of plasma human immunodeficiency virus type 1 RNA and the risk of perinatal transmission. N Engl J Med 341: 394-402.

28. Mofenson LM, Lambert JS, Stiehm ER, Bethel J, Meyer WA, et al. (1999) Risk factors for perinatal transmission of human immunodeficiency virus type 1 in women treated with zidovudine. Pediatric AIDS Clinical Trials Group Study 185 Team. N Engl J Med 341: 385-393. 
Citation: Van Dyke RB, Danner SP, Chrestman S, Kissinger P, Nesheim S, et al. (2015) Outcomes of Infants Born to HIV-Infected Women Identified by Rapid HIV Testing Late in Pregnancy or at Delivery: The MIRIAD Study. J AIDS Clin Res 6: 484. doi:10.4172/2155-6113.1000484

Page 7 of 7

29. The International Perinatal HIV Group (1999) The mode of delivery and the risk of vertical transmission of human immunodeficiency virus type 1--a metaanalysis of 15 prospective cohort studies. The International Perinatal HIV Group. N Engl J Med 340: 977-987.

30. European Mode of Delivery Collaboration (1999) Elective caesarean-section versus vaginal delivery in prevention of vertical HIV-1 transmission: a randomised clinical trial. Lancet 353: 1035-1039.

31. Sperling RS, Shapiro DE, Coombs RW, Todd JA, Herman SA, et al. (1996) Maternal viral load, zidovudine treatment, and the risk of transmission of human immunodeficiency virus type 1 from mother to infant. Pediatric AIDS Clinical Trials Group Protocol 076 Study Group. N Engl J Med 335:1621-1629.

32. American College of Obstetrics and Gynecology Committee on Obstetric Practice (2008) ACOG Committee Opinion No. 418: Prenatal and perinatal human immunodeficiency virus testing: expanded recommendations. Obstet Gynecol 112: 739-742.

33. Nesheim S, Jamieson DJ, Danner SP, Maupin R, O'Sullivan MJ, et al. (2007) Primary human immunodeficiency virus infection during pregnancy detected by repeat testing. Am J Obstet Gynecol 197:149. 